\title{
PATTERN OF REFRACTIVE ERRORS IN SCHOOL CHILDREN IN RURAL TOWN OF BAREILLY DISTRICT
}

\author{
Manu Bansal 1
}

1Assistant Professor, Department of Ophthalmology, Rajshree Medical Research Institute.

\section{ABSTRACT}

\section{BACKGROUND}

The aim of this study is to assess the pattern of refractive errors in school children in rural town of Bareilly district.

\section{MATERIALS AND METHODS}

All the primary school children of rural town attending the eye OPD of Rajshree Medical Research Institute from January 2016 to June 2016, under school screening were included in the study. The students underwent a preliminary ocular examination. All the children with defective vision (VA < 6/9) were selected for detailed ocular examination including VA both for distance and near, objective refraction with auto refractometer followed by streak retinoscopy under cyclopentolate $1 \%$ eye drop, anterior segment and fundus examination. The children with any type of refractive errors on post-mydriatic examination were further evaluated according to the type of refractive error.

Statistical Analysis - Chi square test.

\section{RESULTS}

Prevalence of refractive error was $13 \%$. The most common refractive error was astigmatism followed by myopia.

\section{CONCLUSION}

There is a need to do regular vision screening in school children as refractive error is an important cause of treatable blindness.

\section{KEYWORDS}

Refractive Errors, Myopia, Hypermetropia, Astigmatism, Screening.

HOW TO CITE THIS ARTICLE: Bansal M. Pattern of refractive errors in school children in rural town of Bareilly district. J. Evolution Med. Dent. Sci. 2017;6(3):176-178, DOI: 10.14260/Jemds/2017/43

\section{BACKGROUND}

The World Health Organisation (WHO) has grouped uncorrected RE among the leading causes of blindness and visual impairment in the world. ${ }^{1}$ Childhood blindness is considered as one of the priorities in Vision 2020 - Right to sight. It is estimated that there are 1.4 million blind children in the world, two-thirds of whom live in developing countries and of all these children it is estimated that 2,70,000 live in India. About $80 \%$ of this is avoidable blindness, although a large number of those affected remain blind due to lack of appropriate access to eye care. ${ }^{2}$

During the last decade, studies confirmed that the prevalence of uncorrected refractive errors is high for children in low and middle income countries and have extensive social and economic impacts, such as limiting educational and employment opportunities of economically active persons, healthy individuals and communities. ${ }^{3}$ Uncorrected refractive error may have larger impact on the learning capability and potential of school children.

Financial or Other, Competing Interest: None.

Submission 04-12-2016, Peer Review 29-12-2016,

Acceptance 03-01-2017, Published 09-01-2017.

Corresponding Author:

Dr. Manu Bansal,

\#6, Brijloy Colony,

Near Sood Dharm Kata,

Prem Nagar,

Bareilly-243005,

Uttar Pradesh.

E-mail: docmanubansal@gmail.com

DOI: $10.14260 /$ jemds $/ 2017 / 43$

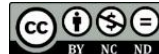

Timely detection and intervention can improve a child's potential tremendously during the formative years. ${ }^{4}$ For India to continue to reap the benefits of the ongoing demographic transition, it is vital that the younger population need to be physically healthy and the country needs to address the health issues urgently.

\section{MATERIALS AND METHODS}

The present study was a descriptive cross-sectional study. Ethical clearance was taken from the Institutional Review Board. All the primary school children of rural town attending the eye OPD of Rajshree Medical Research Institute, Bareilly (U.P.) from January 2016 to June 2016, under school screening were included in the study. A detailed history was taken from all the students including family history, current problems, past problems and treatment. The students then underwent a preliminary ocular examination. An internally illuminated Snellen's chart was used at 6 metre distance for assessment of uncorrected, presenting and best corrected Visual Acuity (VA). Extraocular movements and cover test were performed using torch light and convergence was tested. All the children with defective vision (VA < 6/9) were selected for detailed ocular examination including VA both for distance and near, objective refraction with auto refractometer followed by streak retinoscopy under cyclopentolate $1 \%$ eye drop, anterior segment and fundus examination. The parents of all children were informed about the nature of the study and consent was obtained. The students with history of prior ocular surgery or any ocular disease contributing to the diminished VA, manifest strabismus and pathological myopia were excluded from the study. 
The children with any type of refractive errors on post mydriatic examination were further evaluated according to the type of refractive error.

A spherical equivalent of -0.5 diopter (D) or more was defined as myopia, +1D or more was defined as hypermetropia, and a cylinder refraction greater than $0.75 \mathrm{D}$ was considered as astigmatism.

\section{RESULTS}

A total of 1242 children between 5 and 16 years of age were included in the study. Out of these 662 (53.3\%) were male and $580(46.7 \%)$ were female. The children were divided into 4 groups according to their age (Table 2). Unaided VA worse than $6 / 9$ was present in 162 children, i.e. $13 \%$ of total children (Table 1).

\begin{tabular}{|c|c|c|c|}
\hline Sex & Total (N) & $\begin{array}{c}\text { Cases with } \\
\text { Refractive } \\
\text { Error }\end{array}$ & $\begin{array}{c}\text { Percentage } \\
\text { among Sex } \\
\text { Distribution }\end{array}$ \\
\hline Males & $662(53.3 \%)$ & 90 & $13.6 \%$ \\
\hline Females & $580(46.7 \%)$ & 72 & $12.4 \%$ \\
\hline \multicolumn{3}{|c|}{ Table 1. Sex Distribution of Children } \\
\hline
\end{tabular}

\begin{tabular}{|c|c|c|c|c|}
\hline $\begin{array}{c}\text { Age } \\
\text { (Years) }\end{array}$ & $\begin{array}{c}\text { Total } \\
\text { (N) }\end{array}$ & $\begin{array}{c}\text { Percentage } \\
\text { in Study } \\
\text { Group }\end{array}$ & $\begin{array}{c}\text { Cases with } \\
\text { Refractive } \\
\text { Error } \\
\text { among Age } \\
\text { Groups }\end{array}$ & $\begin{array}{c}\text { Percentage } \\
\text { Distribution } \\
\text { among Age } \\
\text { Groups }\end{array}$ \\
\hline $5-7$ & 181 & $14.6 \%$ & 17 & 9.4 \\
\hline $8-10$ & 270 & $21.7 \%$ & 30 & 11.1 \\
\hline $11-13$ & 339 & $27.2 \%$ & 45 & 13.3 \\
\hline $14-16$ & 452 & $36.4 \%$ & 70 & 15.5 \\
\hline \multicolumn{5}{|c|}{ Table 2. Distribution of Children by Age } \\
\hline
\end{tabular}

In the study maximum children were in 14 to 16 years of age, among them $15.5 \%$ of children had refractive error. Among 5 - 7 years of age, $9.4 \%$ of children had refractive error (Table 2).

\begin{tabular}{|c|c|c|}
\hline Refractive Errors & Total & Percentage among Cases \\
\hline Myopia & 65 & 40.1 \\
\hline Hypermetropia & 12 & 7.4 \\
\hline Astigmatism & 85 & 52.5 \\
\hline \multicolumn{2}{|c|}{ Table 3. Refractive Error Distribution } \\
\hline
\end{tabular}

Among the cases maximum had astigmatism, i.e. 52.5\%, myopia was present in $40.1 \%$ and hypermetropia was present in $7.4 \%$ of cases.

\begin{tabular}{|c|c|c|c|}
\hline $\begin{array}{c}\text { Age } \\
\text { Distribution } \\
\text { (Years) }\end{array}$ & $\begin{array}{c}\text { Myopia } \\
\text { (65) }\end{array}$ & $\begin{array}{c}\text { Hypermetropia } \\
\text { (12) }\end{array}$ & $\begin{array}{c}\text { Astigmatism } \\
\text { (85) }\end{array}$ \\
\hline $5-7$ & $6(9.2 \%)$ & $6(50 \%)$ & $30(35.3 \%)$ \\
\hline $8-10$ & $\begin{array}{c}12 \\
(18.5 \%)\end{array}$ & $3(25 \%)$ & $22(25.9 \%)$ \\
\hline $11-13$ & $\begin{array}{c}17 \\
(26.1 \%)\end{array}$ & $2(16.7 \%)$ & $19(22.4 \%)$ \\
\hline $14-16$ & $\begin{array}{c}30 \\
(46.2 \%)\end{array}$ & $1(8.3 \%)$ & $14(16.5 \%)$ \\
\hline \multicolumn{4}{|c}{ Table 4. Refractive Errors Distribution in Age Groups } \\
\hline
\end{tabular}

The prevalence of myopia progressively increases from $9.2 \%$ in 5 - 7 years to $46.2 \%$ in 14 - 16 years. Prevalence of hypermetropia and astigmatism decreases from $5-7$ years to $14-16$ years. This was statistically significant $(\mathrm{P}<0.05)$.

\section{DISCUSSION}

Childhood blindness is a priority area because of the number of years of blindness that ensues. Data on the prevalence and causes of blindness in children is needed for planning and evaluating preventive and curative services for children. The prevalence of refractive error in this study was $13 \%$, which was similar to prevalence observed by Seema et al of $13.65 \% .{ }^{5}$ Prevalence reported by GVS Murthy ${ }^{6}$ et al was $6.4 \%$ and Kumar et al 7 was $7.4 \%$.

There was an increase in the overall prevalence of refractive errors with advancing age as shown in Table 2. Our results were comparable with the study by Pavithra et $\mathrm{al}^{4}$ and Matta $\mathrm{S}$ et $\mathrm{al}^{8}$ showing increasing prevalence with age.

In our study, astigmatism was the most common refractive error followed by myopia and then hypermetropia (Table 3). This is comparable with the study of Rai et al. ${ }^{9}$ Pavithra et $\mathrm{al}^{4}$ and Matta $\mathrm{S}$ et $\mathrm{al}^{8}$ observed myopia to be the most common refractive error. Medi et al ${ }^{10}$ showed commonest refractive error was astigmatism (52\%) followed by hypermetropia (37\%) and least common was myopia (11\%). In the present study myopia showed an increasing trend with advancing age and hypermetropia and astigmatism showed a decreasing trend with advancing age, which was statistically significant $(\mathrm{p}<0.05)$. Similar pattern was shown by GVS Murthy et $\mathrm{al}^{6}$ and Pavithra et $\mathrm{al}^{4}$ in their studies.

A major limitation of our study was that only school going children were included in the study. Significant proportion of children in rural area do not go to school, hence a complete assessment of visual impairment in children was not possible.

\section{CONCLUSION}

Our collection of data and also the recommendations of other studies support the fact that regular vision screening of school children in India will be very useful in early detection and correction of avoidable problems. This study also supports the studies conducted in other areas that the school age is a high risk group for refractive errors. Children are not aware of their problems and the prevalence of undetected refractive error is high. As recommended in the national and international studies, like all developing countries, India needs to strengthen the school health services.

\section{REFERENCES}

[1] Resnikoff S, Pascolini D, Etya'ale D, et al. Global data on visual impairment in the year 2002. Bull World Health Organ 2004;82(11):844-51.

[2] Govt of India. Annual Report 2003. Ministry of Health and Family Welfare, New Delhi, 2004.

[3] Naidoo KS, Jaggernath J. Uncorrected refractive errors. Indian J Ophthalmol 2012;60(5):432-7.

[4] Pavithra MB, Maheshwaran R, Rani Sujatha MA. A study on the prevalence of refractive errors among school children of 7-15 years age group in the field practice area-s of a medical college in Bangalore. Int J Med Sci Public Health 2013;2(3):641-5. 
[5] Sharma S, Vashisht BM, Kalhan M, et al. Magnitude of refractive errors among school children in a rural block of Haryana. The Internet Journal of Epidemiology 2009;6(2):5.

[6] Murthy GV, Gupta SK, Ellwein LB, et al. Refractive error in children in an urban population in New Delhi. Invest Ophthalmol Vis Sci 2002;43(3):623-31.

[7] Kumar D, Singh JV, Ahuja PC, et al. Ocular morbidity among school children in Sarojini nagar development block of Lucknow. Indian Journal of Community Medicine 1992;17(3):109-13.
[8] Matta S, Matta P, Gupta V, et al. Refractive errors among adolescents attending ophthalmology OPD. Ind J Com Med 2006;31(2):114.

[9] Rai SK, Thapa HB, Gurung N, et al. Pattern of refractive error in primary school children in Rupandehi district, Nepal. Journal of University College Of Medical Sciences 2015;3(1):31-6.

[10] Medi K, Robert M. A survey of prevalence of refractive errors among children in lower primary schools in Kampala district, Uganda. African Health Sciences 2002;2(2):69-72. 